https://doi.org/10.15407/dopovidi2020.10.085

UDC 582.287.539.16: 546.36

\title{
N.Ye. Zarubina
}

Institute for Nuclear Research of the NAS of Ukraine, Kyiv

E-mail: nataliia.zarubina@gmail.com, zarubina@kinr.kiev.ua

\section{${ }^{137} \mathrm{Cs}$ circulation in forest ecosystems on the territory of the Chernobyl exclusion zone (Soil)}

Presented by Corresponding Member of the NAS of Ukraine V.I. Slisenko

Seasonal changes in the content of ${ }^{137} \mathrm{Cs}$ in soils were studied at three forest ecosystems in the territory of the Chernobyl exclusion zone. The soils were selected layer by layer: $A_{0} l, A_{0} f+A_{0} h, 0-5$ and $5-10 \mathrm{~cm}$ with the frequency of once every two weeks during 2013-2015. Intermittent changes in the levels of the specific activity of ${ }^{137} \mathrm{Cs}$ in all studied soil layers during the calendar year were recorded at the sites. The dependences of the content of ${ }^{137} \mathrm{Cs}$ in different soil layers on the season of the year have not been identified. The calculation of correlation coefficients indicates the existence of a relationship between fluctuations in the concentration of radiocaesium only between layers of 0-5 and 5-10 cm. Air temperature and precipitation over different time intervals preceding the sampling do not affect the redistribution of ${ }^{137} \mathrm{Cs}$ in the soil of the forest ecosystems. It has been suggested that the absence of seasonal patterns of changes in the content of ${ }^{137} \mathrm{Cs}$ in soils is associated with its heterogeneity (different amounts of soil biota in each sample).

Keywords: ${ }^{137}$ Cs, circulation, Chernobyl NPP, soil.

1. Introduction. The forest occupies an important place among the components that make up the natural environment. When artificial radionuclides are released into the environment as a result of accidents at nuclear facilities and testing nuclear weapons, forested areas are one of the factors for the formation of primary deposition of the surface layer of the atmosphere; in the intermediate and late stage forest ecosystems serve as a natural barrier in the distribution of radionuclides and a factor of stabilization of the radiation situation. The soil is of particular importance in retention and further nonproliferation of radionuclides beyond forest ecosystems.

Studies of soil contamination by radionuclides resulting from global fallout, carried out in the USA, showed that forest soil is contaminated almost twice as much as field soils, taken at a distance of $500 \mathrm{~m}$ from the forest ones. The study suggested that the forest floor is a barrier to entry for radiocaesium to deeper soil layers. This was associated with higher soil contamination in forests [1]. In soils of the Russian European North after the transfer of radionuclides in forest ecosystems as a result of nuclear weapons testing, the concentration of ${ }^{137} \mathrm{Cs}$ in the upper layer of soil has reached the maximum over decades [2]. In the study [3], it was indicated that the

Ци т у в ан н я: Zarubina N.Ye. ${ }^{137}$ Cs circulation in forest ecosystems on the territory of the Chernobyl exclusion zone (soil). Допов. Наи. акад. наук Укр. 2020. № 10. С. 85-92. https://doi.org/10.15407/dopovidi2020.10.085 
highest content of ${ }^{137} \mathrm{Cs}$ accounted for the top $0-5 \mathrm{~cm}$ soil layer over more than 40 years after testing a thermonuclear charge in 1953 (South-Eastern trail on the territory of the Semipalatinsk Test Site, Kazakhstan). On the territory of the Eastern Ural radioactive trail resulting from the "Mayak" accident in 1957, studies have found that the vertical migration of ${ }^{137} \mathrm{Cs}$ in the soil of forest ecosystems occurs very slowly and the bulk of the radionuclide remains in the upper mineral layer of soil for decades [4].

After the Chernobyl accident, a large number of publications have been devoted to ${ }^{137} \mathrm{Cs}$ soil pollution. The literature discusses such issues as the distribution and redistribution of this radionuclide along the vertical profile of soils, the dependence of ${ }^{137} \mathrm{Cs}$ levels on soil types, composition and amount of humus, etc. [5,6]. The litter layer in forest ecosystems has been found to contain maximum amounts of ${ }^{137} \mathrm{Cs}$ [7]. Assumptions have been made and models have been developed for the further redistribution of this radionuclide in forest soils over time after the radionuclide enters the ecosystem [8]. In the work [9], it was indicated that, with a gradual decrease in the center of the main ${ }^{137} \mathrm{Cs}$ reserve in soils, the maxima of its specific activity will be noticed not in the forest litter layer, but in deeper mineral soil layers. It was found that, on the territory of Ukrainian Polesie, the ratio of gross ${ }^{137}$ Cs reserves in the forest layer and the mineral soil layer directly depends on the type of forest growing conditions [10]. Studies conducted at a distant stage of the development of the accidental situation unambiguously indicate a decrease in the content of ${ }^{137} \mathrm{Cs}$ in the soil of forest ecosystems over time after the accident [11]. However, the expected serious displacement of the center of the main stock of radiocaesium to the underlying mineral soil layers in the forest ecosystems is not observed [12].

Studying the various components of forest ecosystems after the accident, results were obtained indicating the existence of significant fluctuations in the specific activity of ${ }^{137} \mathrm{Cs}$ in them during the calendar year. In lysimetric waters, the maximum concentrations of ${ }^{137} \mathrm{Cs}$ were observed in spring and late summer - early autumn [6]. Non-periodic increases in the mobile forms of this radionuclide were recorded in the soils of forest ecosystems [13]. According to the authors, this may be a consequence of cyclical phenomena in biogeochemical processes associated with the circulation of organic matter. Seasonal variations in ${ }^{137} \mathrm{Cs}$ content exist in various components of forest ecosystems [5]. According to the data [6], the intensity of biogeochemical processes that determine the behavior of radionuclides in the soil-plant system in forest ecosystems is unstable and changes in the annual cycle.

The aim of the work was to study the seasonal variations in the content of ${ }^{137} \mathrm{Cs}$ in various objects of forest ecosystems during the calendar year at a remote stage of the development of the accidental situation. This article discusses changes in the concentration of this radionuclide in the soils (layer-by-layer) of forest ecosystems in the exclusion zone of the Chernobyl nuclear power plant.

2. Materials and methods. Sampling sites. We studied changes of the concentration of ${ }^{137} \mathrm{Cs}$ in the soil of forest ecosystems on the territory of the exclusion zone of the Chernobyl NPP (ChNPP). Sampling sites are located at different distances and directions from the Chernobyl NPP (Fig. 1).

The sampling sites within the Chernobyl exclusion zone possess the following coordinates: Dytiatky $\left(30^{\circ} 07^{\prime} 21.83^{\prime \prime} \mathrm{E}, 51^{\circ} 07^{\prime} 13.37^{\prime \prime} \mathrm{N}\right)$, Paryshiv $\left(51^{\circ} 17^{\prime} 57.54^{\prime \prime} \mathrm{E}, 30^{\circ} 18^{\prime} 17.43^{\prime \prime N}\right)$, Leliv $\left(30^{\circ} 09^{\prime} 36.63^{\prime \prime} \mathrm{E}, 51^{\circ} 19^{\prime} 19.74^{\prime \prime} \mathrm{N}\right)$. 


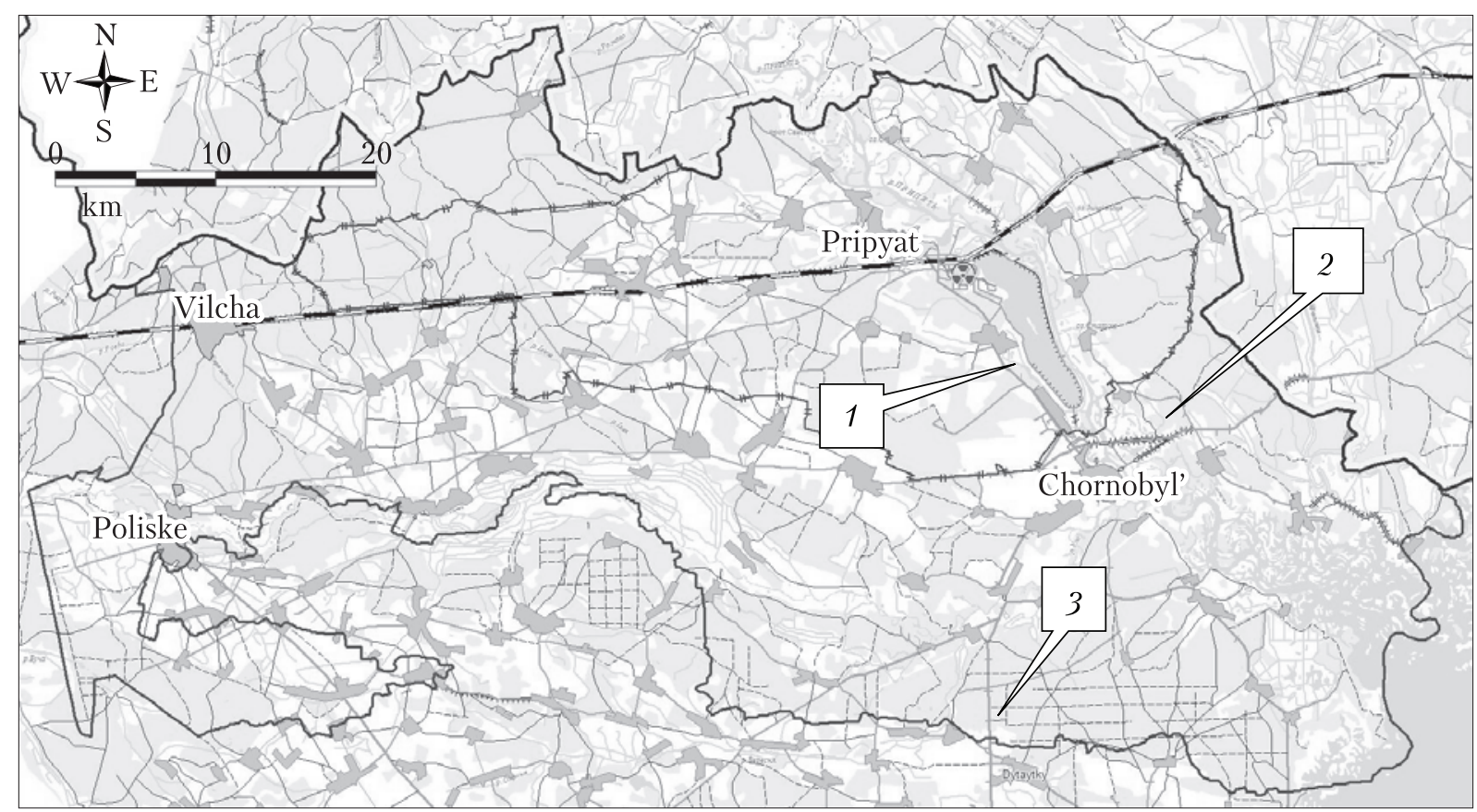

Fig. 1. The sampling sites within the Chernobyl exclusion zone: 1 - Leliv; 2 - Paryshiv; 3 - Dytiatky

Table 1. Main agrochemical characteristics of study soils

\begin{tabular}{|l|c|c|c|c|c|}
\hline \multirow{2}{*}{ Sampling site } & \multirow{2}{*}{$\begin{array}{c}\text { Density, } \\
\mathrm{g} / \mathrm{cm}^{3}\end{array}$} & Humus, \% & $\mathrm{pH}_{\mathrm{KCl}}$, units & \multicolumn{2}{|c|}{$\begin{array}{c}\text { Gross chemical composition } \\
\text { (on a sample of the calcined), wt.\% }\end{array}$} \\
\cline { 5 - 6 } & & & $\mathrm{CaO}$ & $\mathrm{K}_{2} \mathrm{O}$ \\
\hline Leliv & 1.52 & 0.8 & 4.6 & 0.7 & 0.5 \\
Paryshiv & 1.59 & 1.0 & 4.9 & 0.5 & 0.6 \\
Dytiatky & 1.54 & 0.9 & 5.0 & 0.4 & 0.6 \\
\hline
\end{tabular}

Main agrochemical characteristics of the studied soils on the territory of the sampling sites are shown in Table 1. Layer $\mathrm{A}_{0} 1$ at all sites consists of needles, bark, cones, and branches. The layer thickness $A_{0} f+A_{0} h$ is $7 \mathrm{~cm}$ at the Paryshiv and Leliv sampling sites. On the territory of the Dytiatky sampling site, the layer thickness $A_{0} f+A_{0} h$ is $1.5 \mathrm{~cm}$.

The type of ecotope is A1.

Sampling of soil. Soil samples were taken during 2013-2015 once every two weeks. An exception is the beginning of 2013, when samples were taken once a month (January, February and March 2013).

The soils were taken with a cylindrical plastic sampler with a diameter of $60 \mathrm{~mm}$ using an envelope method with a step of $1 \mathrm{~m}: 4$ samples in the corners of the square and 1 sample at the center.

In laboratory conditions, samples were removed from the samplers, and were divided into layers. The soils of each layer from all 5 samplers were mixed, obtaining a representative sample for 


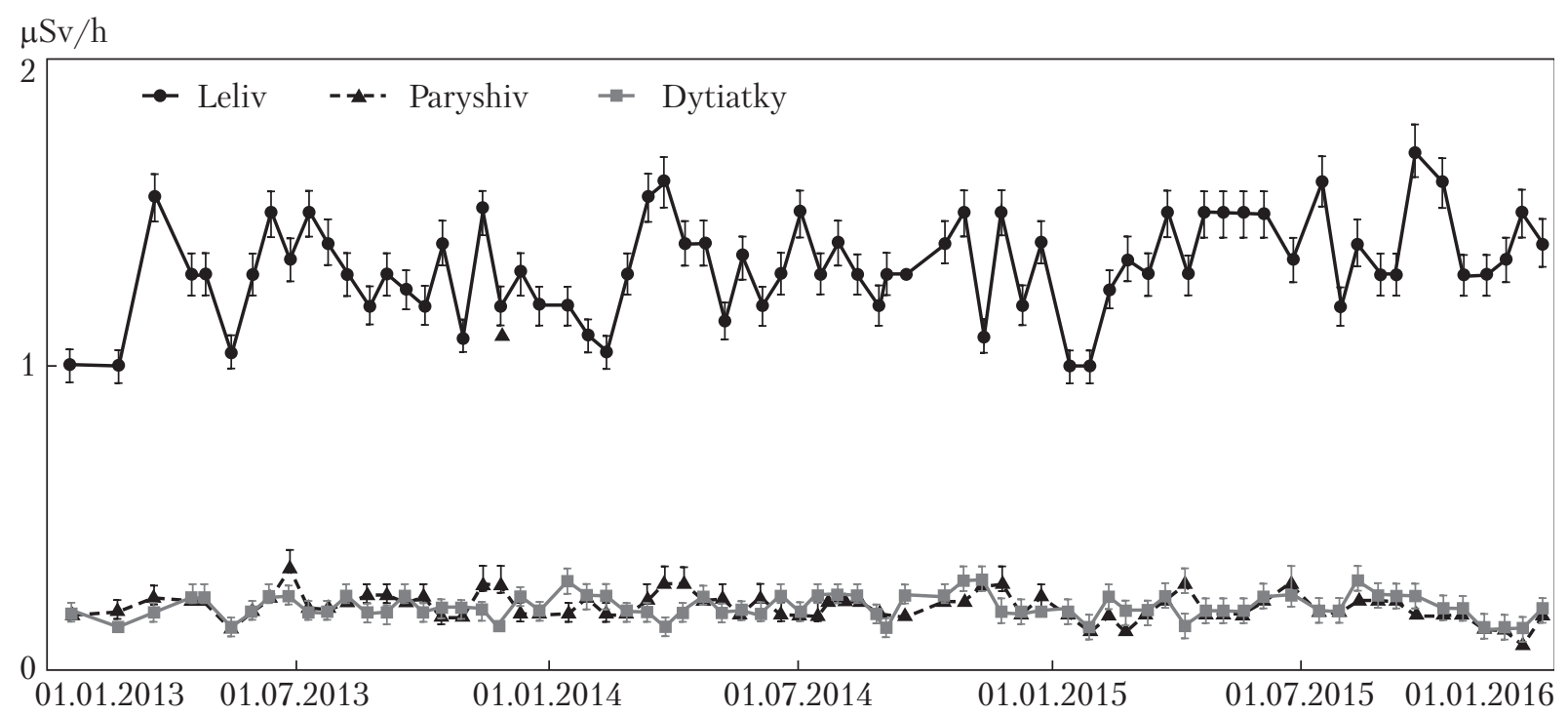

Fig. 2. Equivalent dose rate on the territory of sampling sites

each soil layer. The soil layers $A_{0} 1$ (litter), $A_{0} f+A_{0} h$ (fragmentation and humus horizon), 0-5 and 5-10 cm were selected. Samples of soil layers 0-5 and 5-10 cm were separated from plant roots using laboratory sieves with different hole diameters. Fungal mycelium was not removed from the soil samples. The samples were dried at room temperature for 2 weeks -1 month. Immediately prior to measurements, the weighed samples were taken from the dried samples, which were placed in an oven (at the temperature of $65^{\circ} \mathrm{C}$ ) for 12 hours. After the additional drying, the prepared samples were placed in a disposable calibrated plastic dish with a diameter of $90 \mathrm{~mm}$ for gammaspectrometric measurements.

Before the sampling, the equivalent dose rate was measured on the soil in the sampling sites. The value of this parameter is shown in Fig. 2. The studies have found that the equivalent dose rate is not constant and changes (in some periods of sampling spasmodically) at all sampling sites throughout the calendar year. The instability of this parameter is manifested more intensively at the Leliv site contaminated to a greater extent by radionuclides than the other two ones, located at a distance of about $10 \mathrm{~km}$ from Chernobyl. The fluctuations of EDR reach a large scale on the territory of the Leliv sampling site: from 1.00 to $1.70 \mu \mathrm{Sv} / \mathrm{h}$ with an average of $1.33 \pm 0.16 \mu \mathrm{Sv} / \mathrm{h}$ for the studied period. The maximum EDR value was recorded at the Leliv sampling site in the fall of 2015. The value of the equivalent dose rate during the study period does not show a downward trend at all sampling sites.

Radiometry. ${ }^{137} \mathrm{Cs}$ specific activity measurements were performed employing a CANBERRA gamma-spectrometric set-up based on coaxial highly pure HPGe semiconductor detector, model GC6020.

The detection unit was covered with $100-\mathrm{mm}$ lead protection allowing effective measurements of samples with comparatively low radionuclide specific activity.

Measurement time was from 600 to 14,400 seconds depending on the specific activity of radionuclides. The measurement errors of this series of samples did not exceed $10 \%$ and, as a rule, were in the limits of $3-5 \%$ of the radionuclide activity. 

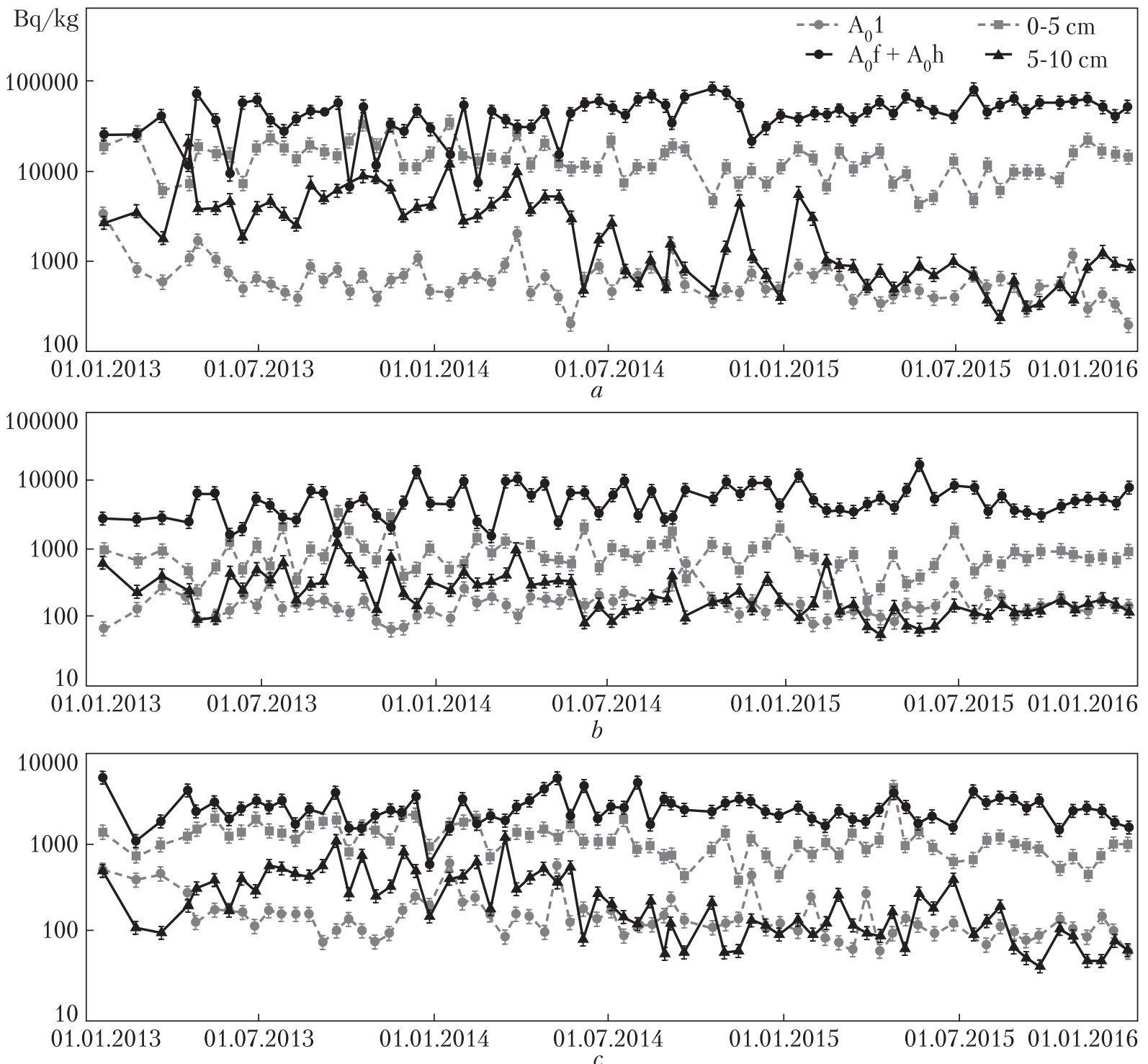

Fig. 3. Specific activity of ${ }^{137} \mathrm{Cs}$ in soil, Bq/kg dry weight. $a$ - Leliv, $b$ - Paryshiv, $c$ - Dytiatky

When carrying out research on the content of radiocaesium $\left({ }^{137} \mathrm{Cs}\right.$ in this work with a halflife of about 30 years) in the same object, it is necessary to exclude the influence of the physical decay of this element on it. Recalculation of the results was carried out on the "zero" date of the event (for 1986/04/26) according to the formula of radioactive decay. The data obtained in this way excluded the influence of that part of the radionuclide that had decayed on the date of each specific sampling. In the study the values of ${ }^{137} \mathrm{Cs}$ activity concentrations in different soil layers are shown, being recalculated using the radioactive decay formula.

In this article, the ${ }^{137} \mathrm{Cs}$ specific activity in samples (dry weight) is given in $\mathrm{Bq} / \mathrm{kg}$.

3. Results and discussion. As a result of the research, significant fluctuations in the levels of specific activity of ${ }^{137} \mathrm{Cs}$ in all studied soil layers during the calendar year were recorded on 
the territories of the sampling sites. The maximum changes in the concentration of radiocaesium (up to 20 times) were observed at the Leliv and Dytiatky sampling sites in the soil layer of 5-10 cm. At the same time, for Paryshiv sampling site, these changes over the course of one year in the 5-10 cm layer are less than 12 times and the maximum differences in the content of this radionuclide are noted in the layer of $0-5 \mathrm{~cm}-15$ times. There is a sharp drop/increase (5-6 times) in the levels of the specific activity of ${ }^{137} \mathrm{Cs}$ (in rare cases up to 14 times - at Leliv sampling site layer 5-10 cm $400 \mathrm{~Bq} / \mathrm{kg}$ dry weight 2014/12/24 and $5770 \mathrm{~Bq} / \mathrm{kg}$ dry weight 2015/01/13) during two samplings (Fig. 3).

At the sampling sites, depending on the date of sampling, from 65 to $85 \%$ of the total ${ }^{137} \mathrm{Cs}$ reserve in soils is in the layer $A_{0} f+A_{0} h$. However, several times during the studied period, the content of ${ }^{137} \mathrm{Cs}$ in the soil layer 0-5 cm exceeds its content in the forest litter layer at each of the sampling sites. The sampling date with a recorded excess of caesium content in the soil layer of $0-5 \mathrm{~cm}$ differs for each sampling site, i.e. this process is not logical and can be considered as a random event.

The studies have found that, in the area of the sampling sites, there is no decrease in the specific activity of ${ }^{137} \mathrm{Cs}$ in the $\mathrm{A}_{0} \mathrm{f}+\mathrm{A}_{0} \mathrm{~h}$ layer during the study period. In other soil layers $\left(\mathrm{A}_{0} \mathrm{l}, 0-5\right.$ and $\left.5-10 \mathrm{~cm}\right)$, a decrease in ${ }^{137} \mathrm{Cs}$ content was noted on the territory of all sampling sites. The maximum rate of decrease in concentrations of radiocaesium is typical of a soil layer of $5-10 \mathrm{~cm}$ at all sampling sites.

The Spearman correlation coefficient between the ${ }^{137}$ Cs content in each soil layer at all sampling sites was calculated (Table 2). At all sampling sites, no correlation was found between fluctuations in the ${ }^{137} \mathrm{Cs}$ content in $\mathrm{A}_{0} \mathrm{f}+\mathrm{A}_{0} \mathrm{~h}$ and other soil layers. The maximum obtained value of the correlation coefficient corresponds to a pair of 0-5 and 5-10 cm. For the Leliv and Dytiatky sampling sites, the correlation coefficient is significant and indicates the presence of a noticeable relationship between fluctuations in the concentration of ${ }^{137} \mathrm{Cs}$ activity in layers $0-5$ and 5-10 cm. Coefficient of 0.417 for the Paryshiv sampling site indicates that there is a moderate relationship between changes in concentrations of radiocaesium in soil layers of 0-5 and 5-10 cm over period of the research.

The studies have shown that, for sites with similar composition of soils located at a relatively small distance from each other, there is no single pattern of fluctuations in the specific activity of ${ }^{137} \mathrm{Cs}$ in soils during the calendar year. This conclusion is also confirmed by the absence of the

Table 2. Spearman correlation coefficients between the content of ${ }^{137} \mathrm{Cs}$ in various soil layers in the territory of sampling sites

\begin{tabular}{|l|r|r|r|}
\hline \multicolumn{1}{|c|}{ Layers } & Leliv & Paryshiv & Dytiatky \\
\hline $\mathrm{A}_{0} \mathrm{l}-\mathrm{A}_{0} \mathrm{f}+\mathrm{A}_{0} \mathrm{~h}$ & -0.036 & 0.030 & 0.075 \\
$\mathrm{~A}_{0} \mathrm{l}-0-5 \mathrm{~cm}$ & 0.149 & 0.145 & 0.076 \\
$\mathrm{~A}_{0} \mathrm{l}-5-10 \mathrm{~cm}$ & 0.309 & 0.149 & 0.206 \\
$\mathrm{~A}_{0} \mathrm{f}+\mathrm{A}_{0} \mathrm{~h}-0-5 \mathrm{~cm}$ & -0.255 & 0.101 & 0.169 \\
$\mathrm{~A}_{0} \mathrm{f}+\mathrm{A}_{0} \mathrm{~h}-5-10 \mathrm{~cm}$ & -0.495 & -0.275 & -0.047 \\
$0-5 \mathrm{~cm}-5-10 \mathrm{~cm}$ & 0.540 & 0.417 & 0.680 \\
\hline
\end{tabular}


${ }^{137}$ Cs circulation in forest ecosystems on the territory of the Chernobyl exclusion zone (Soil)

correlation dependence of the equivalent dose rate fluctuations at the following sampling sites: Leliv-Paryshiv - 0.203; Leliv-Dytiatky - 0.079; Paryshiv-Dytiatky - 0.388.

The Spearman correlation coefficient was calculated between the content of ${ }^{137} \mathrm{Cs}$ in different soil layers and the amount of precipitation preceding samplings for different time intervals. Maximal Spearman correlation coefficients between the specific activity of ${ }^{137} \mathrm{Cs}$ in various soil layers and the amount of precipitation, air temperature preceding the sampling was 0.263 . Therefore, it can be argued that the correlation between these parameters does not reach the level of statistical significance, and precipitation does not directly affect the processes of ${ }^{137}$ Cs redistribution in the soil at the sampling sites. Air temperature is also not a factor in this process.

Significant fluctuations in the levels of the specific activity of ${ }^{137} \mathrm{Cs}$ in the soil of forest ecosystems can be associated with the specific nature of this object. According to data [14], the soil appears to be a very heterogeneous environment with many different microzones. Carrying out sampling under natural conditions, each time soil, that is not completely identical in soil biota content, was taken. The levels of ${ }^{137} \mathrm{Cs}$ specific activity in soil's microzones can be different due to their filling with different types of soil biota.

Apparently, it is because of the differences in the amount and types of soil biota with different levels of the specific activity of ${ }^{137} \mathrm{Cs}$ contained in each sample, changes in the ${ }^{137} \mathrm{Cs}$ content in soils depending on the season were not possible to fix.

With a decrease in the amount of soil biota in the mineral layers of the soil, the movement of ${ }^{137} \mathrm{Cs}$ in these layers can be carried out more intensively than in the layer of forest litter. This may explain significantly larger jumps in the levels of the specific activity of radiocaesium in the soil in a layer of $0-5$ and $5-10 \mathrm{~cm}$.

4. Conclution. As a result of the studies, it was found that the content of ${ }^{137} \mathrm{Cs}$ changes stepwise during the calendar year in the soils of forest ecosystems in the Chernobyl exclusion zone, regardless of the direction and distance from the ChNPP. These abrupt changes in the concentrations of radiocaesium for each soil layer are not associated with the season of the year. Intermittent changes in the equivalent dose rate at the sites are also noted.

The maximum content of ${ }^{137} \mathrm{Cs}$ is characteristic of the forest litter layer. The maximum correlation coefficients were obtained for changing the concentration of this radionuclide in layers of $0-5$ and $5-10 \mathrm{~cm}$.

It was not possible to establish the dependence of changes in the levels of the specific activity of ${ }^{137} \mathrm{Cs}$ on the amount of precipitation and air temperature preceding taking the samples.

It has been suggested that the inability to establish the presence of seasonal changes in the content of ${ }^{137} \mathrm{Cs}$ in soils is due to its heterogeneity (different amounts of soil biota in each sample).

This work was financed by the STCU 5954 project.

\section{REFERENCES}

1. Miller, K. M., Kuiper, J. L. \& Heifer, I. K. (1990). ${ }^{137}$ Cs fallout depth distributions in forest versus field. J. Environ. Radioact., 12, pp. 23-47.

2. Kiselev, G. P., Bazhenov, A. V., Zykov, S. B. \& Kiseleva, I. M. (2001, March). ${ }^{137} \mathrm{Cs},{ }^{232} \mathrm{Th},{ }^{226} \mathrm{Ra},{ }^{40} \mathrm{~K}$ in the soils of the European North. Proceedings of the International Conference Biological effects of small doses of ionizing radiation and radioacontammant of environment (pp. 139-140). Syktyvkar (in Russian). 
3. Artemyev, O. I. \& Umarov, M. A. (2006, December). Radionuclides distribution from the 1953 explosion at the Semipalatinsk test site. Proceeding of the International Scientific Conference Radioactivity after nuclear explosions and accidents, Vol. 2, (pp. 240-253). Moscow (in Russian).

4. Tichomirov, F. A. (1993). Radionuclide distribution and migration in EURT forests. In Ecological after-effects of the radioactive contamination at South Ural (pp. 21-39). S.-Petersburg (in Russian).

5. Perevolotsky, A. N. (2006). Distribution of ${ }^{137} \mathrm{Cs}$ and ${ }^{90} \mathrm{Sr}$ in forest biogeocenoses. Minsk (in Russian).

6. Shcheglov, A. I. (1999). Biogeochemistry of technogenic radionuclides in forest ecosystems. Moscow (in Russian).

7. Rühm, W., Steiner, M., Wirth, E., Dvornik, A., Zhuchenko, T., Kliashtorin, A., Rafferty, B., Shaw, G. \& Kuchma, N. (1996, March). Dynamic of radionuclides behaviour in forest soils. Proceedings of the first International Conference The radiological consequences of the Chernobyl accident (pp. 225-228). Minsk.

8. Ivanov, Y. O. (2001). Dynamics of radionuclide redistribution in soils and vegetation. In Chornobyl. The Exclution Zone (pp. 47-76). Kyiv (in Ukrainian).

9. Bulavik, I. M. \& Perevolotsky, A. N. (1998). Migration of ${ }^{137}$ Cs in forest soils of Belorussian Polesie. Collection of scientific works of Polesskaya ALNIS, Iss. 5, Problems of ecology of forests and forest use on Polissya of Ukraine, pp. 14-21 (in Russian).

10. Landyn, V., Krasnov, V., Kurbet, T., Orlov, O., Savuschyk M. \& Davydov M. (2011). The results of radioecological research in Ukraine forest ecosystems contaminated by Chernobyl Nuclear Power Plant accident releases. Agroecol. J., 1, pp. 53-57 (in Ukrainian).

11. Zarubina, N. E., Malyuk, I. A., Kotishevskaya, E. Yu., Teletskaya, S. V., Golovach, A. I. \& Golovach, L. A. (2009). Seasonal changes of specific activity of ${ }^{137} \mathrm{Cs}$ in soil on the territory of ranges 30-km zones of ChNPP and "the southern trace". Nucl. Phys. Atom. En., 10, No. 4, pp. 413-417 (in Russian).

12. Zibtsev, S. V. (2013). Theoretical and methodological justification of forest monitoring in the zones of radioactive contamination as a result of the accident on Chernobyl NPP. (Extended abstract of Doctor thesis). National University of Life and Environmental Sciences of Ukraine, Kyiv, Ukraine (in Ukrainian).

13. Bondarenko, G. N., Kononenko, L. V., Dolin, V. V., Sushchik, Y. J., Arhipov, A. M. \& Shramenko, I. F. (2001, April). Cyclicity in biogeochemical migration processes ${ }^{137} \mathrm{Cs}$. Proceedings of the International Conference Fifteen years after the Chornobyl accident. Lessons learned (pp. 2-147). Kyiv (in Ukrainian).

14. Dobrovolsky, G. V. (Ed.). (2003). Structural and functional role of soils and soil biota in the biosphere. Moscow (in Russian).

Received 06.08.2020

\section{Н.С.Зарубіна}

Інститут ядерних досліджень НАН України, Київ

E-mail: nataliia.zarubina@gmail.com, zarubina@kinr.kiev.ua

\section{ЦИРКУЛЯЦІЯ ${ }^{137} \mathrm{Cs}$ У ЛІСОВИХ ЕКОСИСТЕМАХ} НА ТЕРИТОРІЇ ЧОРНОБИЛЬСЬКОЇ ЗОНИ ВІДЧУЖЕННЯ (ГРУНТ)

Сезонні зміни вмісту ${ }^{137} \mathrm{Cs}$ у грунтах вивчались у трьох лісових екосистемах на території Чорнобильської зони відчуження. Грунти відбирали пошарово: $\mathrm{A}_{0} \mathrm{l}, \mathrm{A}_{0} \mathrm{f}+\mathrm{A}_{0} \mathrm{~h}, 0-5$ та 5-10 см з частотою один раз на два тижні протягом 2013-2015 років. На ділянках зафіксовано переривчасті зміни рівня питомої активності ${ }^{137} \mathrm{Cs}$ у всіх досліджених шарах грунтів протягом календарного року. Залежності вмісту ${ }^{137} \mathrm{Cs}$ у різних шарах грунту від сезону року не виявлено. Розрахунок коефіцієнтів кореляції свідчить про наявність взаємозв'язку між коливаннями концентрації радіоцезію лише між шарами $0-5$ та 5-10 см. Температура повітря та опади протягом різних часових інтервалів, що передували відбору проб, не впливають на перерозподіл ${ }^{137} \mathrm{Cs}$ у грунті лісових екосистем. Висловлено припущення, що відсутність сезонних закономірностей зміни вмісту ${ }^{137} \mathrm{Cs}$ у грунтах пов'язана з його неоднорідністю (різною кількістю грунтової біоти в кожному зразку).

Ключові слова: ${ }^{137} \mathrm{Cs}$, циркуляція, Чорнобильська АЕС, грунт. 